\title{
DYNAMICS OF INTESTINAL PARASITE INFECTION \\ IN PRZEWALSKI'S HORSES REINTRODUCED TO PRE-URALS STEPPE, ORENBURG STATE NATURE RESERVE (RUSSIA)
}

\author{
Tatjana L. Zharkikh ${ }^{1 *}$, Pavel I. Khristianovsky ${ }^{2,3}$, Rafilia T. Bakirova ${ }^{1}$, Vladimir Yu. Petrov ${ }^{1}$, \\ Evgeniy A. Bulgakov ${ }^{1}$, Dina E. Khuzhakhmetova ${ }^{1}$, Vladislav V. Belimenko ${ }^{4}$, Stanislav A. Platonov ${ }^{2}$ \\ ${ }^{1}$ Joint Directorate of State Nature Reserves «Orenburg» and «Shaitan-Tau», Russia, Russia \\ *e-mail: russian969@yandex.ru \\ ${ }^{2}$ Orenburg State Agrarian University, Russia \\ ${ }^{3}$ Federal Research Centre of Biological Systems and Agrotechnologies of RAS, Russia \\ ${ }^{4}$ All-Russian Institute of Experimental Veterinary, Russia
}

Received: 06.03.2019. Revised: 15.04.2019. Accepted: 20.04.2019.

\begin{abstract}
The first successful reintroduction programme for the Przewalski’s horse in Russia was launched by FSFI «Orenburg Reserves» in 2015. A total of 36 Przewalski's horses were brought to the Pre-Urals Steppe site from semireserves in France and Hungary in 2015-2017. Parasite infections can significantly affect the survival of the wild horses during the process of adaptation. Investigation of the level of helminth infections in these reintroduced horses is the subject of their regular monitoring in the Pre-Urals Steppe. The studies were conducted on the territory of the Pre-Urals Steppe of $165.38 \mathrm{~km}^{2}$, in Orenburg State Nature Reserve in 2016-2019. The coprological examinations were conducted on a monthly basis using the McMaster method. The Baerman-Orlov larvoscopy technique was used to identify the larval stages of nematodes. Przewalski's horses were threatened with anthelmintic drugs every 3 to 12 months. All faecal samples collected in two or more months after deworming, contained eggs of nematodes of the family Strongylidae (Nematoda, Strongylida), the prevalence of infection was $100 \%$. Single eggs of cestodes from the genus Anoplocephala (Cestoidea: Anoplocephalidae) were found in four samples out of 642. Larvoscopy revealed larvae of the nematodes from the genus Triodontophorus (subfamily Strongylinae) and larvae from the subfamily Cyathostominae. In addition, a small number of larvae of the II and III stages of the gastric botfly Gastrophilus spp. (family Gastrophilidae), were found in the faeces in some Przewalski's horses after deworming. Parascaris equorum was not registered in this study, although this parasite was found in domestic horses from the village nearest to the Pre-Urals Steppe. During the study period, there were no noticeable seasonal fluctuations in the number of helminth eggs; the level of EPG (eggs per gram of faeces) value gradually increased in all groups of horses after deworming. A high level of infection (> 500 EPG) was reached in 1-6 months after deworming; the maximal level was registered in September 2018 (2483.3 \pm 718.5 EPG in one of the single-sex groups). The comparatively high EPG values did not affect the physical condition of Przewalski's horses in the Pre-Urals Steppe; no clinical signs of parasite infections were observed in our study. The level of strongylid infection in free-roaming breeding groups of Przewalski's horses was lower than that of animals kept in acclimatization enclosures. There was a noticeable trend towards a decrease in the average EPG level of the breeding groups. This may be due to two factors: 1) contamination of grass in the enclosures was higher because of higher density of horses; 2) the breeding groups transported in 2015 and 2016, had more time for the adaptation. Regular deworming is not recommended for relocated wild horses outside an adaptation period as it may influence their natural resistance to parasitic infections and poses a risk of the emergence of resistant helminth populations. Preventive deworming of the Przewalski's horses should be administered only within the first years after their relocation to new areas.
\end{abstract}

Key words: deworming, Equus ferus przewalskii, helminth infection, parasitology, reintroduction

\section{Introduction}

Over the past century, many animal species have become extinct in the wild, while some have been preserved in artificial habitats like zoos and breeding centres. During the last few decades, successful captive breeding programmes have been implemented to restore natural populations of animals. One of the well- known examples (Soorae, 2011) is the reintroduction of the Przewalski's horse Equus ferus przewalskii Poliakov, 1881, a species that once widely inhabited Eurasian steppes, but disappeared in nature in the middle of the 20th century. These horses have been preserved in zoos around the world for over one hundred years (Boyd \& Houpt, 1994). 
The first successful reintroduction programme for the Przewalski's horse in Russia was launched by FSFI «Orenburg Reserves» in Orenburg Region in 2015 (Bakirova \& Zharkikh, 2019). A semi-free population of the wild horses of at least 100-150 individuals is planned to be established in the Pre-Urals Steppe site of Orenburg State Nature Reserve (hereafter also as Orenburg Reserve) by 2030. Monitoring of the development of the new population and its interaction with the local ecosystems is a prerequisite for a successful reintroduction of these horses into their natural habitats.

Parasite infections can significantly affect the survival of Przewalski's horses during the process of adaptation. Many parasites do not directly cause mortality but do impair body condition; reduce growth or fecundity; or exacerbate pre-existing threats to hosts, such as predation or winter survival (Irvine, 2006). Investigation of the level of helminth infections in these reintroduced horses is the subject of their regular monitoring in the PreUrals Steppe.

The aim of this study was the analysis of the dynamics of infection with gastrointestinal parasites of the Przewalski's horses reintroduced to Orenburg Region.

\section{Material and Methods}

The studies were conducted at the Przewalski's horse Reintroduction Centre on the territory of the Pre-Urals Steppe, in Orenburg State Nature Reserve in 2016-2019. The Orenburg Reserve cluster consists of five sites located in five districts of Orenburg Region; their total area is $381.9134 \mathrm{~km}^{2}$. The Pre-Urals Steppe site of $165.38 \mathrm{~km}^{2}$ became a part of Orenburg Reserve on 13 July 2015. The nearest inhabited area is the village of Sazan, Belyaevka District. Prior to the establishment of the strictly protected nature area, various economic activities were carried out in this area, including the grazing of livestock - cattle, sheep and, to a lesser extent, domestic horses. At present, the whole territory of the Pre-Urals Steppe is fenced to prevent livestock intruding to the area and the migration of introduced Przewalski's horses outside the protected territory (Bakirova \& Zharkikh, 2019).

In 2015-2017, 36 Przewalski's horses, aged 1.5 to 9 years, were brought to the Pre-Urals Steppe (Table 1). Horses of the first transport group were born in the $6 \mathrm{~km}^{2}$ nature semi-reserve Le Villare (France). The second and third transport groups originated from the $30 \mathrm{~km}^{2}$ semi-reserve Pentezug at the Hortobágy National Park (Hungary).

Table 1. Summary on the keeping and anthelmintic treatments of three groups of Przewalski's horses introduced to Pre-Urals Steppe, Orenburg State Nature Reserve (Russia)

\begin{tabular}{|c|c|c|c|c|c|}
\hline $\begin{array}{c}\text { Transportation to } \\
\text { Orenburg Reserve }\end{array}$ & Group & Number of horses & $\begin{array}{l}\text { Period in } \\
\text { acclimatisation } \\
\text { enclosure }\end{array}$ & $\begin{array}{l}\text { Release from } \\
\text { acclimatisation } \\
\text { enclosure }\end{array}$ & $\begin{array}{l}\text { Anthelmintic } \\
\text { treatments }\end{array}$ \\
\hline $\begin{array}{l}\text { 18.10.2015, } \\
\text { from France }\end{array}$ & Breeding F & 6 & Oct 2015 - Oct 2016 & 03.10 .2016 & $\begin{array}{l}17.10 .2015 \\
29.08 .2016 \\
06.08 .2017 \\
17.05 .2018\end{array}$ \\
\hline \multirow{2}{*}{$\begin{array}{l}\text { 20.11.2016, } \\
\text { from Hungary }\end{array}$} & Breeding $\mathrm{H}$ & 9 & Nov 2016 - Sep 2017 & 28.09 .2017 & $\begin{array}{l}19.11 .2016 \\
09.09 .2017 \\
18.04 .2018 \\
14.12 .2018\end{array}$ \\
\hline & $\begin{array}{c}\text { Only-male } \\
1\end{array}$ & 5 & Nov 2016 - present & - & $\begin{array}{l}19.11 .2016 \\
23.08 .2017 \\
03.12 .2017 \\
01.05 .2018 \\
14.12 .2018\end{array}$ \\
\hline \multirow{2}{*}{$\begin{array}{l}\text { 10.10.2017, } \\
\text { from Hungary }\end{array}$} & $\begin{array}{c}\text { Only-male } \\
2\end{array}$ & 4 & Oct 2017 - present & - & $\begin{array}{l}03.12 .2017 \\
01.05 .2018 \\
14.12 .2018\end{array}$ \\
\hline & Only-female & 12 & $\mid \begin{array}{c}\text { Oct } 2017-\text { present } \\
\text { (3 females) } \\
\text { Oct } 2017-\text { Jun } 2018 \\
\text { (6 females) }\end{array}$ & 30.05 .2018 & $\begin{array}{l}15.12 .2017 \\
21.03 .2018 \\
20.01 .2019\end{array}$ \\
\hline
\end{tabular}


Before relocation to Russia, the Przewalski's horses were kept in semi-reserves with natural pastures and have never been dewormed. Before their transportation to the Pre-Urals Steppe, all horses were dewormed with the drug Ivermectin orally at their place of origin. Examination of faecal samples showed no parasite infection in the horses of the first and second transport groups at the time of their relocation to the Reintroduction Centre. The horses of the third transport group showed a high level of parasite infection at the time of their delivery to the Pre-Urals Steppe probably due to the failure of drug application. These horses were dewormed again in the Reintroduction Centre with the macrocyclic lactone drug «Univerm» $(0.2 \%$ aversectin C, PharmBioMed, Russia) (Table 1). The decision to stop further deworming treatments in 2019 has been taken.

Horses were brought to the Reintroduction Centre in autumn, when the activity of bloodsucking insects and ticks is minimal or absent. During this time, the development of the larvae of gastrointestinal strongylid nematodes is slow due to temperatures below zero. After their arrival, all groups of Przewalski's horses were kept in the acclimatisation enclosures $\left(0.45 \mathrm{~km}^{2}\right.$ each) with natural steppe pasture vegetation. In winter, they were provided with additional hay ad libitum. After acclimatisation, two breeding groups (harems) were released from their enclosures to the main territory of the Pre-Urals Steppe. Later, six mares from the third transport group were also released. During the study, the rest of the imported Przewalski's horses were kept in the enclosures.

The groups were kept on pasture plots which were previously used in different ways. The horses of the breeding groups were kept in the acclimatisation enclosures with minimal contamination with helminths as there had been a few specimens of domestic horses entering this territory before the establishment of the protected area. After their release, the Przewalski's horses from France inhabited a territory that had been completely free from livestock for one year. On arriving, the Hungarian harem group was placed in an acclimatisation enclosure that had been free from grazing by ungulates for the previous two years. Single-sex groups were placed in the acclimatisation enclosures where the harem groups were previously kept.

Body condition, general activity and behaviour of the imported Przewalski's horses were routinely evaluated. All horses have been tested regularly on the presence of eggs of the gastrointestinal parasites in their faeces. From August 2016 to May 2018, Przewalski's horses were regularly dewormed with the macrocyclic lactone drug «Univerm» (see Table 1). In December 2018 and January 2019, the anthelmintic «Prasiver» was used $(1 \mathrm{ml}$ contains the active ingredients: praziquantel $-25 \mathrm{mg}$ and ivermectin $-5 \mathrm{mg}$ ). The medications were mixed with food and provided to all animals in a group. However, the consumption of the drug by each animal was watched.

Since August 2016, the coprological examinations of all horses have been conducted at the Reintroduction Centre on a monthly basis using the McMaster method (Herd, 1992) with a sensitivity of 25 eggs per gram of faeces (EPG). A total of 642 samples were collected for coproovoscopy. The results for different groups were compared using the nonparametric Wilcoxon signed-rank test (Ivanov, 1990). Differences with $\mathrm{p}>0.05$ were considered statistically insignificant.

The Baerman-Orlov larvoscopy technique was used to identify the larval stages of nematodes (Indiryakova et al., 2004). In November 2016 and May 2017, 21 faecal samples were collected from Przewalski's horses imported from France. Three faeces samples were collected from Hungarian Przewalski's horses in March and May 2017. Also, 3 faecal samples from domestic horses Equus caballus Linnaeus, 1758 were collected in November 2016, March and May 2017 for the comparison with Przewalski's horses. The domestic horses belonging to private owners from the nearest village of Sazan, graze freely in the territory adjoining to the Pre-Urals Steppe. Coproovoscopy of the samples from domestic horses was made using the Fülleborn's flotation technique.

\section{Results}

Body conditions of the studied Przewalski's horses were good in all seasons. The level of parasite infection of these horses was indeterminable by their appearance. The results of the coproovoscopy of Przewalski's horses from different groups are presented in Fig. 1 and Fig. 2. All faecal samples collected in two or more months after deworming, contained eggs of nematodes of the family Strongylidae (Nematoda, Strongylida), the prevalence of infection was $100 \%$. The highest level of horse infection varying from 250 to 3900 EPG (eggs per gram) was registered in sum- 
mer and early autumn. The difference in EPG values between different groups of horses was not statistically significant $(\mathrm{p}>0.05)$. However, despite more frequent deworming of the single-sex groups, their infection level was higher than in harem groups, especially in animals of the third transport group. The infection level was the lowest in the harem group from France. It was noted, that over the study period, some individuals had a permanently low or permanently high level of EPG value in comparison with the average mean values for their groups.

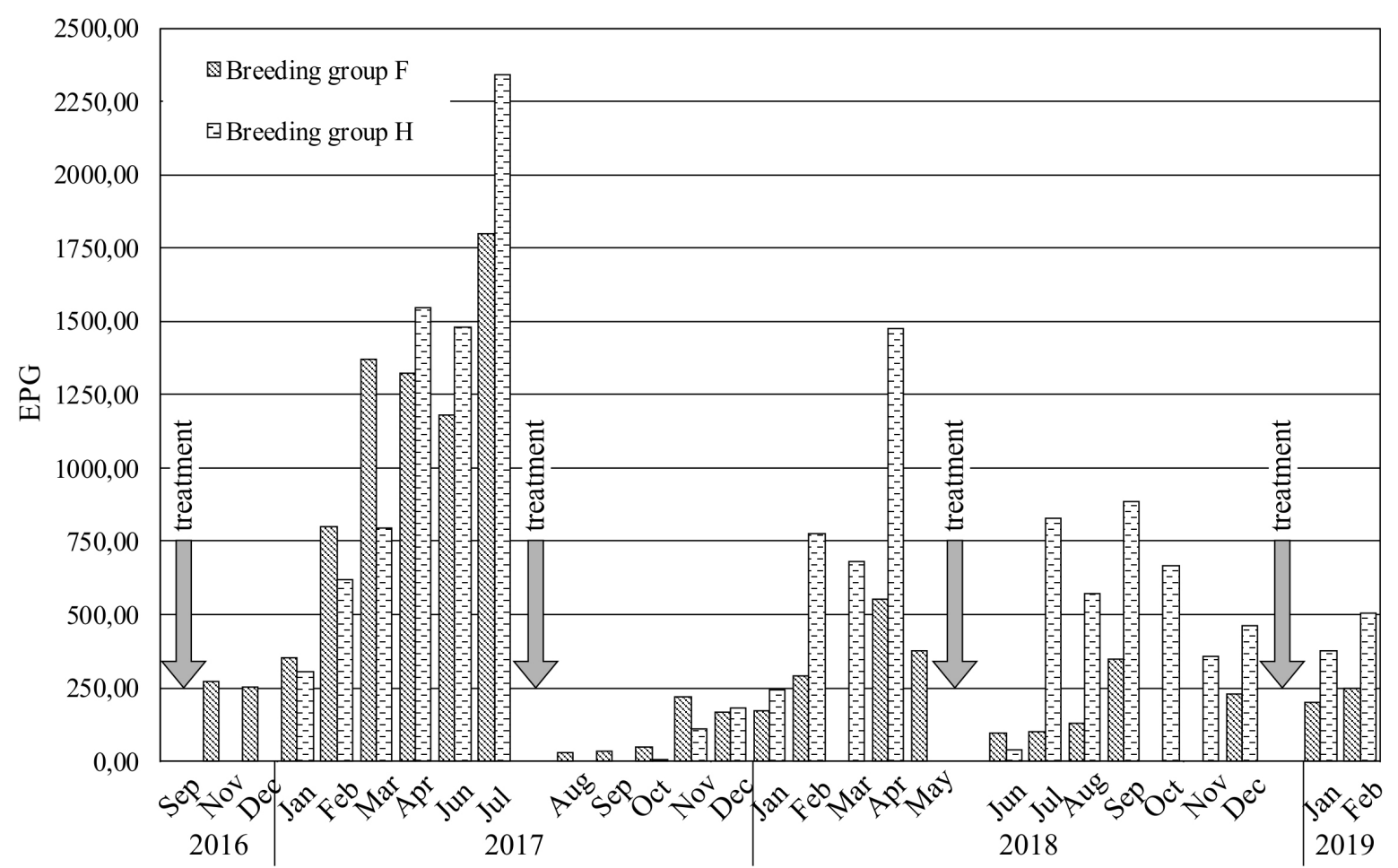

Fig. 1. Dynamics of infection in breeding groups of Przewalski's horses in the Pre-Urals Steppe, Orenburg Reserve with strongylid nematodes, eggs per gram (EPG).

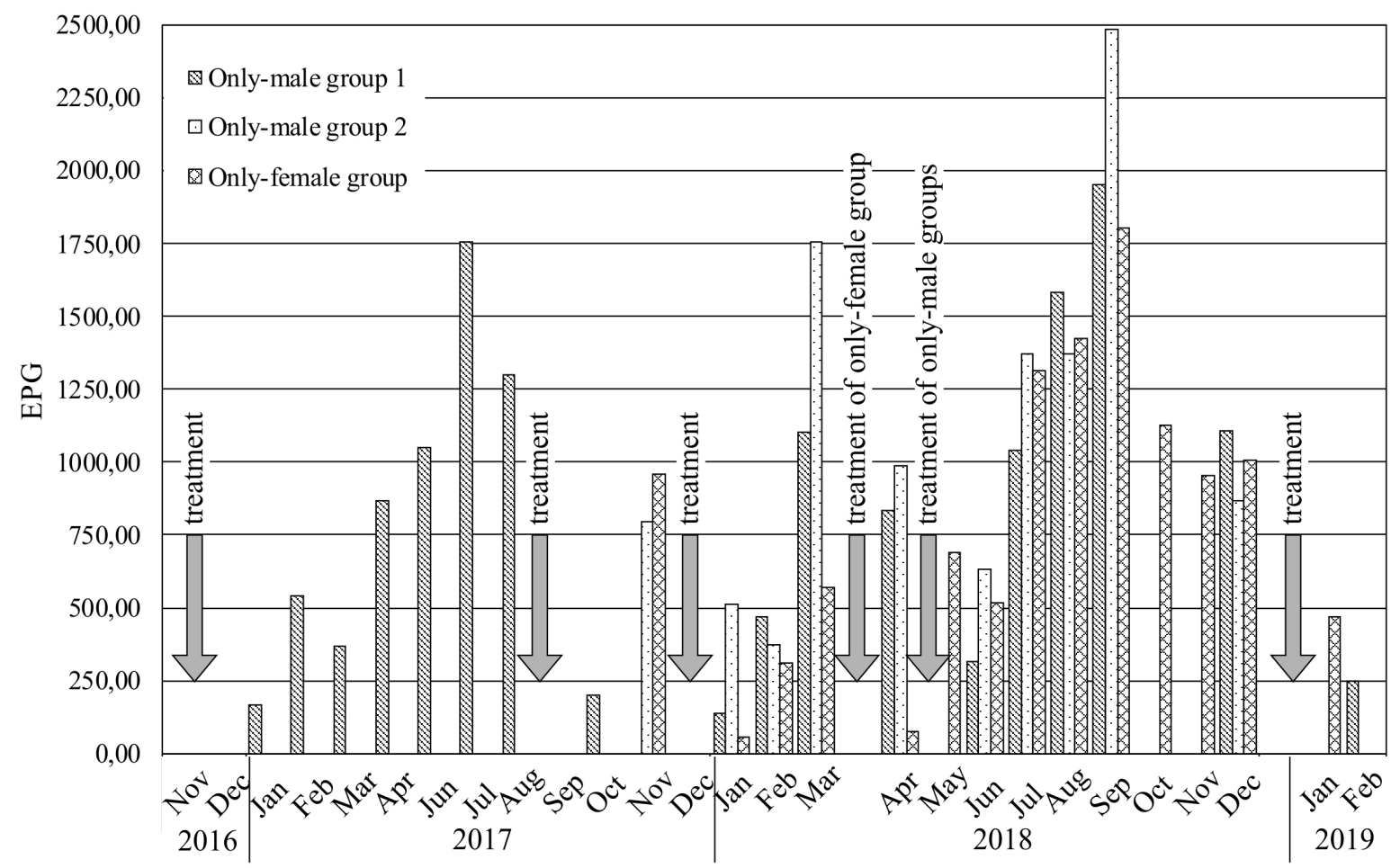

Fig. 2. Dynamics of infection in single-sex groups of Przewalski's horses in the Pre-Urals Steppe, Orenburg State Nature Reserve (Russia) with strongylid nematodes, eggs per gram (EPG). 
In August and October 2018, single eggs of cestodes from the genus Anoplocephala (Cestoidea: Anoplocephalidae) were found in four samples from three Przewalski's horses (one egg in three samples, two eggs in one sample).

Larvoscopy revealed larvae of the nematodes from the genus Triodontophorus (subfamily Strongylinae) in all samples of the breeding group from France. Larvoscopy of the samples collected from horses from Hungary revealed larvae of the nematodes from the subfamily $\mathrm{Cy}-$ athostominae (old syn. Trichonematinae). In addition, a small number of larvae of the II and III stages of the gastric botfly Gastrophilus spp. (family Gastrophilidae) were found in faeces of some Przewalski's horses after deworming.

Coproovoscopy of samples from domestic horses showed that they were infected with strongylid nematodes (family Strongylidae) with a medium level of infection and with Parascaris equorum (Goeze, 1782) (family Ascarididae) with a low level of infection. Larvoscopy of the faecal samples revealed larvae of Strongylus edentatus (Looss, 1900) (subfamily Strongylinae) and small strongylids (subfamily Cyathostominae).

\section{Discussion}

In a previous study conducted in August 2016, 19 species of nematodes (18 species of the family Strongylidae and Habronema muscae Carter, 1861) and one species of botflies from the genus Gasterophilus were found in the breeding group from France (Kuzmina et al., 2017). In the present study, no new species of intestinal parasites were found in Przewalski's horses, despite the fact that some new animals had arrived from Hungary. No specimens of Parascaris equorum (Nematoda: Ascarididae), Anoplocephala spp. or Paranoplocephala spp. (Cestoda: Anoplocephalidae) were found in faecal samples of the studied Przewalski's horses. These parasites are large in size and well discernible with the naked eye. However, individual eggs of Anoplocephala were registered with coproovoscopy in 2018. The above mentioned cestodes are common in domestic horses and are ubiquitous (Taylor et al., 2015). Parascarids have been registered in domestic horses from the village of Sazan; thus, it is possible that the territory of PreUrals Steppe site is contaminated by this parasite. Parascaris equorum is pathogenic especially for young horses (Taylor et al., 2015).

Despite the fact that the Przewalski's horses in Pre-Urals Steppe have different origins (arrived from different populations) and were kept under different horse-keeping conditions, the levels of their infection with gastrointestinal helminths were similar in all groups. During the study period, there were no noticeable seasonal fluctuations in the number of helminth eggs; the level of EPG value gradually increased in all groups of horses after deworming. Studies on feral domestic horses showed that deworming significantly changed the seasonal dynamics of parasite infection (Wood et al., 2013). Przewalski's horses imported from Hungary in late autumn 2016, could not be infected with a large amount of helminth larvae as the average daily temperature was $-11^{\circ} \mathrm{C}$ and the snow cover was stable during the first month after their arrival. The increase in the EPG value was connected with development of encysted larvae that preserved in the walls of the large intestine of the Przewalski's horses and therefore avoided influence of anthelmintic drugs. It is also possible that the level of infection is more influenced by horse immunity than by season, especially during the adaptation to new environmental conditions over the first months after transportation.

The level of horse infection with strongylids higher than 500 EPG for adult domestic horses is considered as high (Kaplan \& Nielsen, 2010). In the Przewalski's horses in the PreUrals Steppe, this level was reached in one to six months after deworming (Fig. 1, Fig. 2). The rationale of regular deworming of horses kept on pasture is quite controversial. Since the $1960 \mathrm{~s}$, resistance to anthelmintics has been observed in horse parasitic nematodes (Kaplan \& Nielsen, 2010), and the diversity and wide geographical distribution of Cyathostominae populations resistant to benzimidazoles or macrocyclic lactones (ivermectin), explain the recent widespread infections among horses subjected to regular deworming (Sangster \& Dobson, 2002; Matthews, 2014). The benefits of controlling parasites in threatened species, to improve fitness and population performance, then, must be balanced with the individual ethical and ecosystem costs associated with control (Stringer \& Linklater, 2014). Some cases of mortality of imported Przewalski's horses caused by helminth infections were reported for the Hustain Nuruu reintroduction project in Mongolia (Bouman, 1995). Those animals originated from European zoos and semi-reserves, where they were dewormed two to four times 
a year according to the standard protocols of the European Endangered Species Programme for the Przewalski's horse (Zimmermann, 2000). If parasites are eradicated from a population, future generations of the host species will not have immunological experience with that parasite (Stringer \& Linklater, 2014). Possibly, regularly dewormed Przewalski's horses were poorly adapted to infection with parasites, which are common in natural conditions.

This was one of the reasons to seek founder horses for the Orenburg reintroduction programme not in zoos but in European semireserves. Several generations of Przewalski's horses in donor populations (France and Hungary) are kept and bred in conditions as close as possible to natural ones. This contributes to the natural selection of animals with good resistance to parasite infections. In our opinion, this is why comparatively high EPG values did not affect the physical condition of Przewalski's horses in the Pre-Urals Steppe; no clinical signs of parasite infections were observed in our study. A good physical body condition of the Przewalski's horses could also be an explanation of their resistance to parasites. A high productivity of palatable vegetation in the Pre-Urals Steppe (Fedorov et al., 2018) and additional feeding of the horses when necessary resulted in their good body condition the year-round.

In general, the level of strongylid infection in free-roaming breeding groups of Przewalski's horses was lower than that of animals kept in acclimatisation enclosures. There was a noticeable trend towards a decrease in the average EPG level of the breeding groups. This may be due to two factors: 1) the contamination of grass in the enclosures was higher because of a higher density of horses; 2) the breeding groups transported in 2015 and 2016 had more time for adaptation.

Considering the above, a certain level of infection may be beneficial if Przewalski's horses show no clinical signs of parasite infections. Animals acquire some level of immunity and, subsequently, better tolerate infection with local helminth species. Preventive deworming of the Przewalski's horses should be administered only within the first years after their relocation to new areas.

\section{Conclusions}

The imported Przewalski's horses adapted well to the new habitats as there were no clini- cal signs of helminth infections recorded. In the studied Przewalski's horses, nematodes of the family Strongylidae formed the predominant group of parasites. Parascaris equorum was not registered in our study, although this parasite was found in domestic horses in the village nearest to the Pre-Urals Steppe.

Prevalence of infection reached $100 \%$ in about two months after their deworming. A high level of infection (> 500 EPG) was reached in 1-6 months after deworming; the maximal level was registered in September 2018 (2483.3 \pm 718.5 EPG in one of the single-sex groups).

Regular deworming is not recommended for relocated wild horses outside an adaptation period as it may influence their natural resistance to parasitic infections and poses a risk of the emergence of resistant helminth populations.

It is necessary to continue studying parasite communities of the Przewalski's horses and the dynamics of parasitic infection with focus on seasonality and age of horses.

\section{Acknowledgements}

We are very grateful to Dr Tetyana A. Kuzmina (Institute of Zoology NAS of Ukraine) and Natalya S. Zvegintsova (Biosphere Reserve «Askania Nova», Ukraine) for their kind supervision of the initial stage of parasitological investigations of Przewalski's horses at Orenburg State Nature Reserve, and for their critical review of this article.

\section{References}

Bakirova R.T., Zharkikh T.L. 2019. Programme on establishing a semi-free population of Przewalski's horse in Orenburg State Nature Reserve: the first successful project on the reintroduction of the species in Russia. Nature Conservation Research 4(Suppl. 2): 57-64. DOI: $10.24189 /$ ncr.2019.025

Bouman I. 1995. Re-introduction of Przewalski horses in Hustain Nuruu. Przewalski horse 36: 16-29.

Boyd L., Houpt K.A. (Eds). 1994. Przewalski's Horse: the History and Biology of an Endangered Species. New York: State University of New York Press. 313 p.

Fedorov N.I., Mikhailenko O.I., Zharkikh T.L., Bakirova R.T. 2018. Mapping of Vegetation with the Geoinformation System and Determining of Carrying Capacity of the Pre-Urals Steppe area for a Newly Establishing Population of the Przewalski Horse Equus ferus przewalskii at the Orenburg State Nature Reserve. IOP Conference Series: Earth and Environmental Science 107(1): 012100. DOI: 10.1088/1755-1315/107/1/012100

Herd R.P. 1992. Performing equine fecal egg counts. Veterinary Medicine 87: 240-244. 
Indiryakova T.A., Romanova E.M., Klimin V.N. 2004. Methods of laboratory diagnosis of helminthiasis in domestic animals and humans. Ulyanovsk: UGSHA. 210 p. [In Russian]

Irvine R.J. 2006. Parasites and the dynamics of wild mammal populations. Animal Science 82(6): 775-781. DOI: 10.1017/ASC2006106

Ivanov A.A. 1990. Basic statistics. Moscow: Fizkultura i sport. 86 p. [In Russian]

Kaplan R.M., Nielsen M.K. 2010. An evidence-based approach to equine parasite control: It ain't the 60s anymore. Equine Veterinary Education 22(6): 306-316. DOI: 10.1111/j.2042-3292.2010.00084.x

Kuzmina T.A., Zvegintsova N.S., Zharkikh T.L. 2017. Gastrointestinal parasite community in a new population of the Przewalski's horse (Equus ferus przewalskii) in the Orenburg State Reserve, Russia. Vestnik Zoologii 51(3): 243-250. DOI: 10.1515/vzoo-2017-0030

Matthews J.B. 2014. Anthelmintic resistance in equine nematodes. International Journal of Parasitology: Drugs and Drug Resistance 4(3): 310-315. DOI: 10.1016/j. ijpddr.2014.10.003
Sangster N.C., Dobson R.J. 2002. Anthelmintic resistance. In: D.L. Lee (Ed.): The Biology of Nematodes. London: Taylor \& Francis. P. 531-567.

Soorae P.S. (Ed.). 2011. Global Re-introduction Perspectives: 2011. More case studies from around the globe. Gland, Switzerland: IUCN/SSC Re-introduction Specialist Group and Abu Dhabi, UAE: Environment Agency-Abu Dhabi. 250 p.

Stringer A.P., Linklater W. 2014. Everything in Moderation: Principles of Parasite Control for Wildlife Conservation. BioScience 64(10): 932-937. DOI: 10.1093/biosci/biu135

Taylor M.A., Coop R.L., Wall R.L. 2015. Veterinary Parasitology. Chichester John Wiley \& Sons. 1032 p.

Wood E., Matthews J., Stephenson S., Slote M., Nussey D. 2013. Variation in fecal egg counts in horses managed for conservation purposes: Individual egg shedding consistency, age effects and seasonal variation. Parasitology 140(1): 115-128. DOI: 10.1017/ S003118201200128X

Zimmermann W. (Ed.). 2000. EEP Asiatic Equids: Husbandry guidelines. Cologne: Zoologischer Garten Koln, Schilling Verlag Munster. 


\title{
ДИНАМИКА ЗАРАЖЕННОСТИ КИШЕЧНЫМИ ПАРАЗИТАМИ ЛОШАДЕЙ ПРЖЕВАЛЬСКОГО, РЕИНТРОДУЦИРОВАННЫХ В ПРЕДУРАЛЬСКУЮ СТЕПЬ, ГОСУДАРСТВЕННЫЙ ПРИРОДНЫЙ ЗАПОВЕДНИК «ОРЕНБУРГСКИЙ» (РОССИЯ)
}

\author{
Т. Л. Жарких ${ }^{1 *}$, П. И. Христиановский ${ }^{2,3}$, Р. Т. Бакирова ${ }^{1}$, В. Ю. Петров ${ }^{1}$, \\ Е. А. Булгаков ${ }^{1}$, Д. Е. Хужахметова ${ }^{1}$, В. В. Белименко ${ }^{4}$, С. А. Платонов ${ }^{2}$
}

${ }^{1}$ Объединенная дирекиия государственных природных заповедников «Оренбургский» и «Шайтан-Тау», Россия

*e-mail: russian969@yandex.ru

${ }^{2}$ Оренбургский государственный аграрный университет, Россия

${ }^{3}$ Федеральный исследовательский иентр биологических систем и агротехнологий РАН, Россия

${ }^{4}$ Всероссийский научно-исследовательский институт экспериментальной ветеринарии, Россия

Первая успешная программа реинтродукции лошади Пржевальского в России была запущена ФГБУ «Заповедники Оренбуржья» в 2015 г. 36 лошадей Пржевальского были завезены на участок «Предуральская степь» из полурезерватов Франции и Венгрии в 2015-2017 гг. Паразитарные инфекции могут значительно повлиять на выживание диких лошадей в процессе адаптации. Исследование уровня гельминтозных инфекций у реинтродуцированных лошадей является предметом регулярного мониторинга в Предуральской степи. Работа проводилась на территории Предуральской степи площадью 165.38 км², в Оренбургском государственном заповеднике в 2016-2019 гг. Копрологические исследования выполнялись ежемесячно по методу МакМастера. Метод ларвоскопии Бермана-Орлова был использован для идентификации личиночных стадий нематод. Регулярная дегельминтизация лошадей Пржевальского проводилась с промежутком от 3 до 12 месяцев. Все образцы фекалий, собранных через два или более месяцев после дегельминтизации, содержали яйца нематод семейства Strongylidae (Nematoda, Strongylida), экстенсивность инвазии составила 100\%. Одиночные яйца цестод из рода Anoplocephala (Cestoidea: Anoplocephalidae) были обнаружены в четырех образцах из 642. Ларвоскопия выявила личинок нематод рода Triodontophorus (подсемейство Strongylinae) и личинок из подсемейства Cyathostominae. Кроме того, небольшое количество личинок II и III стадии желудочного овода Gastrophilus spp. (семейство Gastrophilidae) были обнаружены в фекалиях у некоторых лошадей Пржевальского после дегельминтизации. В данном исследовании не были зарегистрированы Parascaris equorum, хотя этот паразит был обнаружен у домашних лошадей из ближайшего к Предуральской степи села. В течение периода исследования не было заметных сезонных колебаний количества яиц гельминтов; уровень EPG (яиц в 1 грамме фекалий) постепенно повышался во всех группах лошадей после дегельминтизации. Высокий уровень инфекции (> 500 EPG) наблюдался через 1-6 месяцев после дегельминтизации; максимальный уровень был зарегистрирован в июле $(2341.7 \pm 324.1$ EPG в одной из репродуктивных групп, обитающих на вольном выпасе). Сравнительно высокие значения EPG не влияли на физическое состояние лошадей Пржевальского в Предуральской степи; клинических признаков паразитозов в нашем исследовании не наблюдалось. Уровень зараженности стронгилидами лошадей репродуктивных групп, обитающих на вольном выпасе, был ниже, чем у животных, содержащихся в акклиматизационных загонах. Отмечена тенденция к снижению среднего уровня EPG в репродуктивных группах. Это может быть связано с двумя факторами: 1) паразитарная контаминированность загонов выше из-за более высокой плотности поголовья; 2) у лошадей репродуктивных групп, завезенных в 2015 и 2016 гг., было больше времени для их адаптации. Вне периода адаптации не рекомендуется регулярная дегельминтизация диких лошадей, перевезенных в другие места, так как это может повлиять на их естественную устойчивость к паразитарным инфекциям и создает риск появления устойчивых популяций гельминтов. Профилактическую дегельминтизацию лошадей Пржевальского следует проводить только в течение первых лет после их переселения в новые места.

Ключевые слова: Equus ferus przewalskii, гельминтозная зараженность, дегельминтизация, паразитология, реинтродукция 